\title{
Rising Trend in Caesarean Section Rate: A Community Health Hazard
}

\author{
Soumya Ranjan Panda ${ }^{1 *}$, Madhu Jain ${ }^{2}$ and Shuchi Jain ${ }^{3}$ \\ ${ }^{1}$ Senior Resident, Department of Obstetrics and Gynaecology, India \\ ${ }^{2}$ Professor \& Head, Department of Obstetrics and Gynaecology, India \\ ${ }^{3}$ Assistant Professor, Department of Obstetrics and Gynaecology, India
}

Received: October 19, 2017; Published: October 25, 2017

*Corresponding author: Soumya Ranjan Panda, Senior Resident, Department of Obstetrics and Gynecology, IMS, BHU, UP, India; Tel: 9460379740; Email:drsome4141@gmail.com

\begin{abstract}
Excessive and unnecessary use of caesarean sections is growing as a major problem for women's health for which both developed as well as developing countries are the victims. There is no evidence to show any benefit either to mother or to infant when the procedure is not medically indicated. For a community the ideal rate of caesarean section beyond which there appears to be a null benefit to either mother or fetus is considered to be between 10\%-15\%. But recent studies from various countries show a much higher rate of caesarean section. This rate is even higher in private sectors. 'On demand caesarean section' or 'caesarean section on maternal request' is growing as a new indication for various social or personal reasons. This alarming rate should be stopped as soon as possible. Proper counselling should be given to labouring women. Antenatal education regarding merits and demerits of caesarean section at community level can be an useful tool.
\end{abstract}

Keywords: Caesarean Section; Antenatal Education; Vaginal Delivery

Abbreviations: AHS: Annual Health Survey; RDS: Respiratory Distress Syndrome; ICMR: Indian Council of Medical Research

\section{Introduction}

Though caesarean section can be life saving for mother and baby in certain situations, its excessive and unnecessary use is becoming a matter of concern. Although once it was limited to western countries, now days the rising trend of caesarean sections is more of a global problem. For nearly 30 years, the international healthcare community has considered the ideal rate for caesarean sections to be between $10 \%$ and $15 \%$ [1]. There is no evidence to show any benefit either to mother or to infant when the procedure is not medically indicated [2]. On the other hand there is high chance of associated short and long term risk which can extend many years beyond the index delivery and affect the health of the woman, her child, and future pregnancies. These risks are higher in women with limited access to comprehensive obstetric care [3-5]. The procedure is not that simple and needs to be performed only when clinically justified.

\section{Discussion}

\section{Burden of the Problem}

The rate of caesarean section varies from country to country even region to region. A systematic review by Soto-Vega E et al. [6] in 2015 demonstrated an overwhelming prevalence of caesarean section, with a mean of $42.5 \%$ worldwide. While $65.84 \%$ is worldwide mean of caesarean section in private sector, it is 33.99 $\%$ for public sectors. Datas from countries like Iran, Brazil and México show section rates reaching upto 91.9\%, 85.8\%, and 85.6\%, respectively $[7,8]$, also the same countries have the highest rate of caesarean section in public sector being 78.5\%, 71.0\% and $47.8 \%$ respectively [9]. Countries like Egypt, Turkey, Dominican Republic, Georgia and China have all had over 30 percent increase in their caesarean section rates over the last 24 years. For example, in Egypt, according to the latest data, more than half of all women give birth by caesarean section without much difference between urban and rural areas [10].

Data's from India also show a disturbing increase in caesarean section rates over the last 20 years. A collaborative study done by the Indian Council of Medical Research (ICMR) in the 1980s showed a Caesarean section rate of 13.8 percent in teaching hospitals [11]. The escalating rates of Caesarean sections in teaching hospitals in India had been compared between 1993-94 and 1998-99, with data from 30 medical colleges/teaching hospitals [12]. The overall rate showed an increase from 21.8 per cent in 1993-94 to 25.4 per cent in 1998-99. What was alarming was that 42.4 per cent were primigravidas and 31 per cent had come from rural areas. In a study over a two-year period in an urban area of India, the total 
Caesarean section rates even in the public and charitable sectors were 20 and 38 per cent respectively. In the private sectors, the rate was an unbelievable 47\% [13]. More recently in 2010-2011, the Annual Health Survey (AHS) data in India from 284 districts in nine States, including Jharkhand, found that the median caesarean section rate in the private sector was $28 \%$, compared with $5 \%$ in the public sector [14].

\section{Cause of this Increase Trend}

Although such high levels of caesarean rates cannot be justified, some possible reasons those have been reprted for this are fear of pain; concerns about genital modifications after vaginal delivery; misconception that CS is safer for the baby; the convenience for health professionals and also for the mother and family; fear of medical litigation and lower tolerance to any complications or outcomes other than the perfect baby [15-20]. Some cultural factors also have been found. For example, in China, choosing the date of the baby's delivery on the basis of luck and fate for the future of the baby by some people is one of the explanations for scheduling a CS [21]. High-risk patients do not show a large variation in Caesarean rates, regardless of where they deliver. The largest variation occurs in the low-risk patient category, specifically the nulliparous patient with term singleton foetuses with vertex presentation without other complications. Studies from India as well as from other countries have confirmed that in this group of women perinatal morbidity and mortality rates are not improved by the performance of a Caesarean section [22-24].

The introduction of the concept of 'on demand caesarean section' as a new indication has raised many eyebrows. Mackenzie et al [25] observed that maternal request was one of the main indications for CS (23\%) in 1996.There is too many unknown facts about the true risks and benefits of the procedure. Inadequately informed women choose caesarean section to avoid painful natural childbirth. Most of them like to maintain the vaginal tone of teenagers. But, this is more likely a benefit to the sexual partner than the woman herself. In India, the family sometimes demands that the baby be born on a auspicious date and time, obviously by caesarean section, as dictated by horoscope/astrological calculations. This happens to be a popular indication of caesarean section in China as already described. There are many more reasons for on demand caesarean section which are beyond the scope of this review to be discussed. Moreover, FIGO [26] states that performing caesarean section for nonmedical reasons is ethically not justified.

\section{Associated Risks}

Various studies have confirmed that there is higher incidence of PPH, postpartum infection, chronic abdominal pain, rehospitalisation after elective caesarean section performed in nulliparous low risk women compared to that after vaginal delivery [27-29]. Babies are also vulnerable to unnecessary risks from rising CS rates. The first danger to the baby is the $1 \%$ to $9 \%$ chance that the surgeon's knife will accidentally lacerate the fetus (6\% in nonvertex presentation) [30]. A much more serious risk is respiratory distress syndrome (RDS) in preterm infants and for other forms of respiratory distress in mature infants [31]. Even with repeated ultrasound scans, there may be errors in judging when to do an elective CS. As CS rates rise, so do premature births.

Recurrent caesarean section, scar rupture, hysterectomy, caesarean scar pregnancy and maternal and fetal deaths are some of the future important risks. Previous caesarean section increases the risk of multiple placental abnormalities like placental abruption, placenta previa, and adherent placentation in subsequent pregnancies [32]. While first birth caesarean section had a $30 \%$ increased risk for placental abruption [33], Women who had four or more deliveries with a single caesarean section had a 1.7 fold increased risk of placenta previa. Among women with placenta previa, the incidence of placenta accrete is almost 10\% [34]. Zaki et al. [35] reported a $60 \%$ rate of placenta accrete with three or more caesarean deliveries. The leading indication for caesarean hysterectomy in USA is plaenta accrete [36]. As the incidence of CS continues to rise worldwide, the problem of placenta previa and placenta accrete and consequently caesarean hysterectomy is likely to become more common. Obstetricians should be ready to face these future consequences of today's decision of performing caesarean section [37].

\section{Conclusion}

The proliferating increased rates of caesarean section have not only affected the developed countries but also expanded to developing countries like India. A lot of risks both immediate and remote have been associated with caesarean section but is largely unknown to the population experiencing the process. Health education especially antenatal education regarding safety of vaginal delivery and the cons of caesarean section would be a valuable tool to be offered at population level. As proposed by WHO in 2015 the use of the Robson Classification system as a global standard for assessing, monitoring and comparing caesarean section rates $[38,39]$ will allow analyses of caesarean section rates according to important maternal and fatal variables (e.g. parity, previous caesarean section delivery, onset of labour, gestational age, number of foetuses and presentation).

\section{Conflict of Interest}

There is no conflict of interest between the authors.

\section{References}

1. World Health Organization (1985) Appropriate technology for birth. Lancet 2(8452): 436-437.

2. Hannah ME, Hannah WJ, Hewson SA, Hodnett ED, Saigal S, et al. (2000) Planned caesarean section versus planned vaginal birth for breech presentation at term: a randomised multicentre trial. Term Breech Trial Collaborative Group. Lancet 356(9239): 1375-1383.

3. Lumbiganon P, Laopaiboon M, Gulmezoglu AM, Souza JP, Taneepanichskul S, et al. (2010) Method of delivery and pregnancy outcomes in Asia: the WHO global survey on maternal and perinatal health 2007- 08. Lancet 375(9713): 490-499.

4. Villar J, Carroli G, Zavaleta N, Donner A, Wojdyla D, et al. (2007) Maternal and neonatal individual risks and benefits associated with caesarean delivery: multicentre prospective study. BMJ 335(7628): 1025.

5. Souza JP, Gulmezoglu A, Lumbiganon P, Laopaiboon M, Carroli G, et al. (2010) Caesarean section without medical indications is associated 
with an increased risk of adverse short-term maternal outcomes: the 2004-2008 WHO Global Survey on Maternal and Perinatal Health. BMC medicine 8: 71 .

6. Soto Vega E, Casco S, Chamizo K, Flores Hernández D, Landini V, et al. (2015) Rising Trends of Caesarean Section Worldwide: A Systematic Review. Obstet Gynecol Int J 3(2): 73.

7. Ghotbi F, Akbari Sene A, Azargashb E, Shiva F, Mohtadi M, et al. (2014) Women's knowledge and attitude towards mode of delivery and frequency of cesarean section on mother's request in six public and private hospitals in Tehran, Iran, 2012. J Obstet Gynaecol Res 40(5) 1257-1266.

8. Mendoza Sassi RA, Cesar JA, Silva PR, Denardin G, Rodrigues MM (2010) Risk factors for cesarean section by category of health service. Rev Saude Publica 44(1): 80-89.

9. Hopkins K, de Lima Amaral EF, Mouräo AN (2014) The impact of payment source and hospital type on rising cesarean section rates in Brazil, 1998 to 2008. Birth 41(2): 169-177.

10. Ministry of Health and Population (2014) El-Zanaty Associates, ICF International. The 2014 Egypt Demographic and Health Survey (2014 EDHS). Main Findings, Cairo, Egypt.

11. Indian Council of Medical Research (1990) Collaborative study on high risk pregnancies and maternal mortality (ICMR task force study). ICMR, New Delhi, India.

12. Kambo I, Bedi N, Dhillon BS, Saxena NC (2002) A critical appraisal of caesarean section rates at teaching hospitals in India. Int J Gynaecol Obstet 79(2): 151-158.

13. Sreevidya S, Sathiyasekaran BWC (2003) High caesarean rates in Madras (India): a population-based cross-sectional study. BJOG 110(22): 106111.

14. Randive B, Diwan V, De Costa A (2013) India's conditional cash transfer programme (the JSY) to promote institutional birth: is there an association between institutional birth proportion and maternal mortality? PLoS ONE 8: e67452.

15. Zwecker P, Azoulay L, Abenhaim HA (2011) Effect of fear of litigation on obstetric care: a nationwide analysis on obstetric practice. Am Perinatol 28(4): 277-284.

16. Hellerstein S, Feldman S, Duan T (2015) China's 50\% caesarean delivery rate: is it too high? BJOG 122(2): 160-164.

17. Abdel Aleem H, Shaaban OM, Hassanin AI, Ibraheem AA (2013) Analysis of cesarean delivery at Assiut University Hospital using the Ten Group Classification System. Int J Gynaecol Obstet 123(2): 119-123.

18. Torloni MR, Betran AP, Montilla P, Scolaro E, Seuc A, et al. (2013) Do Italian women prefer caesarean section? Results from a survey on mode of delivery preferences. BMC Pregnancy Childbirth 13:78.

19. Angeja AC, Washington AE, Vargas JE, Gomez R, Rojas I, et al. (2006) Chilean women's preferences regarding mode of delivery: which do they prefer and why? BJOG 113(11): 1253-1258.

20. Torloni MR, Daher S, Betran AP, Widmer M, Souza JP, et al. (2011) Portrayal of caesarean section in Brazilian women's magazines: a 20 year review. BMJ 342: d276.
21. Mi J, Liu F (2014) Rate of caesarean section is alarming in China. Lancet 383(9927): 1463-1464.

22. O’Driscoll K, Foley M (1987) Caesarean section and perinatal outcome. Am J Obstet Gynecol 158: 449-452.

23. Mukherjee J, Bhattacharya PK, Lahiri TK, Samaddar JC, Mehta R (1993) Perinatal mortality in caesarean section: a disturbing picture of unfulfilled expectations. J Indian Med Assoc 91(8): 202-203.

24. Mehta A, Apers L, Verstraelen H, Temmerman M (2001) Trends in Caesarean section rates at a maternity hospital in Mumbai, India. J Health Popul Nutr 19(4): 306-312.

25. Mackenzie IZ, Cooke I, Annan B (2003) Indications for cesarean section in a consultant unit over the decades. J Obstet Gynecol 23(3): 233-238.

26. FIGO Committee for the Ethial Aspects of Human Reproduction and women's Health (1999) Ethical aspects regarding cesarean delivery for non-medical reasons. Int J Obstet Gynecol 64: 217-221.

27. Wang B, Zhou L, Coulter D, Liang H, Zhong Y, et al. (2010) Effects of caesarean section on maternal health in low risk nulliparous women: a prospective matched cohort study in Shanghai, China. BMC Pregnancy and Childbirth 10: 78.

28. Lydon Rochelle M, Holt VL, Martin DP, Easterling TR (2000) Association between method of delivery and maternal rehospitalization. JAMA 283(18): 2411-2416.

29. Almeida EC, Nogueira AA, Candido dos Reis FJ, Rosa e Silva JC (2002) Caesarean section as a cause of chronic pelvic pain. Int J Gynaecol Obstet 79(2): 101-104

30. Smith JF, Hernandez C, Wax JR (1997) Fetal laceration injury at caesarean delivery. Obstet Gynecol 90(3): 344-346.

31. Wagner M (1994) Pursuing the birth machine: the search for appropriate birth technology. ACE Graphics, Naperville, Illinois.

32. Zelop C, Heffner LJ (2004) The downside of cesarean delivery: short and long term complications. Clin Obstet Gynecol 47(2): 386-393.

33. Lydon Rochelle M, Holt VL, Easterling TR (2001) First-birth caesarean and placental abruption or previa at second birth. Obstet Gynecol 97(5): 765-769.

34. Miller DA, Choller JA, Goodwin TM (1997) Clinical risk factors for placenta previa accreta. Am J Obstet Gynecol 177(1): 210-214.

35. Zaki Z, Bahar AM, Ali ME, Albar HA, Gerais MA (1998) Risk factors and morbidity in patients with placenta previa accreta compared to placenta previanon-accreta. Acta Obstet Gynecol Scand 77: 391-394.

36. Catanzarite VA, Lorrain MS, Schrimmer DR (1996) Managing placenta previa accreta. Contemp Obstet Gynecol 41(5): 66-95.

37. Chung CL, Cheng PJ, Liang CC, Lee JD, Soong YK, et al. (1977) Obstetrical hysterectomy and placenta previa / accreta. Three bladder injury case reports. Change Gung Med J 20(1): 44-51.

38. WHO Statement on Caesarean Section Rates. World Health Organization, Geneva, Switzerland, p. 8.

39. Betrán AP, Torloni MR, Zhang J, Gülmezoglu AM, WHO Working Group on Caesarean Section (2016) WHO Statement on caesarean section rates: a commentary. BJOG 123(5): 667-670. 


$\begin{array}{ll}\text { BIOMEDICAL } & \text { Assets of Publishing with us } \\ \text { RESEARCHES } & \text { Global archiving of articles } \\ & \text { - Immediate, unrestricted online access } \\ & \text { - Rigorous Peer Review Process } \\ & \text { - Authors Retain Copyrights }\end{array}$

